\title{
Occupational Hazards of Cashew Workers in Kerala
}

\author{
D. Kinslin, D. Jaya Kumar
}

\begin{abstract}
India is the major exporter of processed cashews, to put it more precisely it is about 65percent of global cashew exports. Cashew is an export-oriented commodity, earning considerable foreign exchange for the country. Much of the processed cashew export from India happens from Kollam, the world's cashew processing capital. Cashew processing companies employ more women than men and are a labour intensive industry. Women workers constitute a major segment in cashew processing industry and roughly more than 90 per cent of the workers in cashew processing units are women. Participation of women in economic activities has reduced their financial dependency on their family but, at the same time it has given rise to several complex health problems for them. Various macro and micro economic factors such as imposing of high import duty of 9.36 per cent on raw cashews by the Union government and frequent layoffs because of lack of raw materials have resulted in the loss of job by several thousand of skilled labourers. This is creating unnecessary mental stress also for the workers. The working environment of cashew workers has been the object of scholarly and policy concerns for long. However, many of the insecurities hitches the lives of cashew workers starting from health hazards to lack of effective social protection seem to have persisted till dateIn this context, this study aims to reveal the occupational health hazards of cashew workers in Kollam district of Kerala.
\end{abstract}

Keywords--- Cashew Industry, Cashew Processing, Occupational Health Hazards, Cashew Workers.

\section{INTRODUCTION}

Cashew processing business is the most prominent business in the southern town of Kollam also known as Quilon in Kerala. As per 2018 statistics, approximately 8, 17,045 MT of raw cashews are imported into Kollam, Kerala for processing. After processing these processed cashews are exported to various countries. It generates annual export earnings of about Rs. 5000 crore and provides stable employment. About 3 lakhs people are employed directly in the cashew processing industry. Cashew factories operate under private, public and co-operative sectors in Kollam. Cashew workers are employed in processing factories work under conditions that are considered to be hazardous for employees. More than the workplace related issues, cashew workers face several hazards that are related to their work. Cashew workers are often exposed to physical hazards like heat and burns, chemical hazards like exposure to skin irritants, biological hazards like various insect bites and diseases caused by bacteria and viruses, ergonomic hazards such as repetitive movements, poor body positioning etc., and psychological hazards such as mental stress and pressure. According to World Health Organization, each year 160 million new cases of workrelated illnessoccur and take 1.7 million lives $(3$ percent of

Revised Manuscript Received on July 10, 2019.

D. Kinslin, Assistant Professor, Emirates College for Management and Information Technology (ECMIT), Dubai.

D. Jaya Kumar, Research Scholar, Faculty of Management Studies, Noorul Islam Centre for Higher Education, Thuckalay, T.N, India. all deaths). Selected occupational risks are responsible worldwide for 37 percent of back pain, 16 percent of hearing loss, 13 percent of chronic obstructive pulmonary diseases, 11 percent of asthma, 8 percent of injuries, 9 percent of lung cancer, and 2 percent of leukemia and caused 850,000 deaths worldwide. Occupational health and safety are primary to the effective and efficient operations of the workforce. Takala et al., (2006) observed that all over the world there are about 430 million people were affected by occupational accidents and occupational diseases annually. Thus, this study aims to find out the most common workplace hazards confronted by the workers in the cashew processing industry.

\section{OBJECTIVES}

This study aims is to find various occupational health hazards of the workers employed in the cashew processing industry in Kollam district, Kerala. The study also analyse the living condition of cashew workers in the Kollam district

\section{SCOPE OF THE STUDY}

The study has been conducted primarily in the district of Kollam, covering all the employees including each one company from Private, Public and Cooperative sectors. Employees from shelling, peeling, roasting, grading, packing and steaming were selected proportional to their total numbers.

\section{METHODOLOGY}

A structured questionnaire was developed and administered to all the participants and information is sought on issues like physical health as well as mental health of workers. Biological hazards a well as non-biological hazards were also. For convenience and ease of use hazards have been split into five types and three major hazards under each head is grouped to form one type of hazard. Physical hazards in the context of a cashew processing factory are from the heat generated from the kiln, dust arising from the shelling and roasting and manual handling of the cashew throughout the process including carrying them on heads. Chemical exposure of cashew employees include caustic cashew sap which causes dermatitis and dry skin, toxic fumes which is the smoke coming out of the kiln which causes various respiratory diseases and poison ingestion.

Biological hazards include the threat from insects like mosquitoes, un-hygienically maintained toilet which causes urinary tract and other such infections and contagious diseases like flu and other diseases spread from one

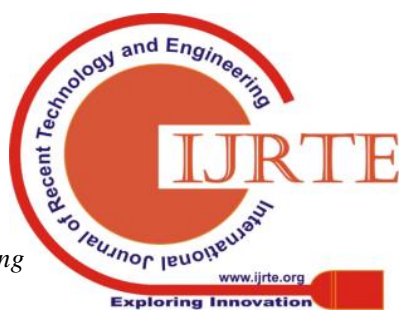


employee to another. Ergonomical hazards include repetitive movements used such as in shelling and peeling which causes joint pains, uncomfortable work place sitting positions which cause back pains and poor body positioning in almost all the works involved with processing cashews. Psycho-sociological issues include stress related to work, issues related to work life balancing and support which means general work support from supervisors and employers which can affect the effectiveness and efficiency of an employee in the cashew processing factory. Data collection for the study was done by the researcher himself from June 2018 to September 2018.

\section{SAMPLING DESIGN}

The health condition of workers in the cashew industry is a diagnostic type of survey. A single stage sampling design was adopted for the study. As sample respondents, 150 workers were randomly selected from 6 companies and care was taken to include workers from all the divisions such as shelling, peeling, roasting and grading.

\section{ANALYSIS \& RESULTS}

\begin{tabular}{|l|l|l|l|}
\hline Hazard Type & \multicolumn{1}{|c|}{ Specific Hazard } & Frequency & Percentage \\
\hline \multirow{4}{*}{ Physical } & Heat & 35 & 23.33 \\
\cline { 2 - 4 } & Dust & 139 & 92.67 \\
\cline { 2 - 4 } & Manual Handling & 145 & 96.67 \\
\hline \multirow{5}{*}{ Biological } & Chemical Exposure & 45 & 30 \\
\cline { 2 - 4 } & Toxic Fumes & 67 & 44.67 \\
\cline { 2 - 4 } & Poison Ingestion & 9 & 6 \\
\hline \multirow{5}{*}{ Ergonomical } & Insects & 98 & 65.33 \\
\cline { 2 - 4 } & $\begin{array}{l}\text { Contagious } \\
\text { Diseases }\end{array}$ & 12 & 8 \\
\cline { 2 - 4 } & Unhygienic Toilets & 112 & 75 \\
\hline & $\begin{array}{l}\text { Repetitive } \\
\text { Movement }\end{array}$ & 87 & 58 \\
\cline { 2 - 4 } & $\begin{array}{l}\text { Uncomfortable } \\
\text { Work Place }\end{array}$ & 92 & 61.33 \\
\cline { 2 - 4 } & $\begin{array}{l}\text { Poor Body } \\
\text { Positioning }\end{array}$ & 56 & 37.33 \\
\hline \multirow{3}{*}{$\begin{array}{c}\text { Psycho- } \\
\text { sociological }\end{array}$} & Stress & 107 & 71.33 \\
\cline { 2 - 4 } & Coping Issues & 101 & 67.33 \\
\cline { 2 - 4 } & Social Support & 124 & 83 \\
\hline
\end{tabular}

\section{DISCUSSION}

The health issues of cashew workers are a matter of long term concern. But, the workers get along with the issues. Other than Biological hazards, all other are contracted after a long term period of exposure to the causes. Major type of Hazards were Psycho-sociological, Physical, Ergonomical, Biological and Chemical in that order. From the table, it can be inferred that psycho-sociological factors are the major factors affecting cashew workers having a mean score of 73.89 as mean percentage score. Even though physical factors such as Dust and Manual Handling of goods posed main issues for the workers, as a whole Psycho-sociological factors scored the highest mean score. Individually, Manual handling of goods and Dust posed major hazards followed by lack of Social Support.

\section{PSYCHO-SOCIOLOGICAL HAZARDS:}

Psycho-sociological workplace hazards induces psychological as well as physiological damage to individual worker. Occupational stress is one of the major hazard which can be directly correlated to poor quality of life and poor work life balance. Stress arises out of feeling of job insecurity, long working hours, work intensification etc. without proper social support from the part of employers and their superior workers. Its no surprise that this type of hazards were ranked high by the employees as the major hazards in their work place. The impact of psychosociological hazards are that they induce and intensify other physiological issues in the human body.

\section{PHYSICAL HAZARDS:}

Physical hazards have been ranked as posing more impact than others such as Biological, Ergonomical and Chemical hazards. Physical hazards in cashew processing industry mainly come from Heat, Dust and Manual Handling of goods. Among these manual handling of goods causes safety issues and accordingly it has been ranked high among the three physical hazards listed here. Falls, temperature, and other factors which can harm the worker without necessarily touching are the major physical hazards inducing fear among workers.

\section{ERGONOMICAL HAZARDS:}

Repetitive movements, Uncomfortable work place and Poor body positioning are common in work places especially in factory settings and cashew factories are also pose ergonomical hazards to their employees. These factors together cause joint pain, back pain, wrist pain, neck pain, shoulder pain etc., are some of the common outcome of ergonomical hazards in factories.

\section{BIOLOGICAL HAZARDS:}

Bites and stings from insects such as mosquitoes which cause dermatitis and other contagious diseases, and unhygienically maintained toilets are the major source of biological hazards as far as the cashew processing workers are concerned. Un-hygienically maintained toilets have been ranked as posing major biological hazard in cashew workers especially female workers followed by insect bites and contagious diseases.

\section{CHEMICAL HAZARDS:}

Chemical hazards are ranked last in the list, as there is no emission of toxic gases and other chemicals from cashew processing industry. Those in shelling bear the permanent burn marks of the caustic cashew sap in hands. This cause dermatitis and dry skin in workers engaged in shelling department. Inhaling of smoke result in chronic respiratory illness and allergic asthma in the long term. 


\section{CONCLUSION}

Almost all the occupation involve in them some hazards and cashew factories are not an exception to this type of hazards. In cashew processing industries the hazards are relatively less when compared to other high risk occupations. Still, it poses Physical, Chemical, Ergonomical. Biological and Psycho-sociological hazards to the employees. Though the hazards are split in this study for convenience, the end result for the employees are necessarily overlapping with one another. For example, Psycho-sociological hazards cause mental stress which in the long run cause other diseases caused by physical, chemical, ergonomical or biological hazards. Now, its for the employers to take necessary steps to prevent the risk of hazards in the cashew processing industries such as providing gloves, neat and clean environment including hygienically maintained toilets, ensuring minimum exposure to toxic gases and giving moral support to the suffering employees.

\section{REFERENCES}

1. Takala J. ,\&Saarela, K. L., (2006), Global estimates of occupational accidents, Safety Science, 44, p 137-156.

2. Mohod, A., S. Jain and A.G. Powar, 2010. Pollution Sources and Standards of Cashew Nut Processing. Am. J. Environ. Sci., 6: 324-328

3. Anderson, Gunnar B.J. (1985). "Posture and Compressive Spine Loading; Intradiscal Pressures, Trunk Myoelectric Activities, Intra Abdominal Pressures and Biomechanical.

4. Chatterjee, D.S. (1987). "Repetition Strain Injury - A Recent Review", Journal of the Society of Occupational Medicine, Vol. 37, No. 4: 100-105.

5. DarishPadmathy, S.C. (1990) Health Conditions of Women Workers in Cashew Nut Industry; A Study of Selected Units in Kaliyikkavilai Village of Kanyakumari District.

6. Government of India (1954) Report on an Enquiry into the Conditions of Labour in the Cashew Nut Processing Industry in India, Chandigarh: Labour Bureau.

7. Government of India (1982) Report on Working and Living Conditions of Workers Engaged in the Cashew Nut Processing Industry in Kerala, Chandigarh: Labour Bureau.

8. Government of India (1999) Report on Socio-economic Conditions of Women Workers in Selected Cashew Nut Processing Units in Selected States (1999), Chandigarh: Labour Bureau.

9. Government of India (2001) Report of the Working Group on Occupational safety and Health for the tenth Five Year Plan (2002-2007). September. New Delhi: Planning Commission.

10. Harilal, K.N. (2003) International Trade in Cashew. Draft paper, preliminary phase report for IIED/CDS/IDS cashew research project in India.

11. James, Rachel (1981). Casual Workers in the Cashew Industry - A Profile. Interim Report No. 10, Indo-Dutch Kerala Research Project. Amsterdam: Centre for Anthropological and Sociological Studies.

12. Kannan K. P. (1978) Employment, Wages and Conditions of Work in the Cashew Processing Industry. CDS Working Paper No. 77, September. Trivandrum: Centre for Development Studies.

13. Krishnakumar S. (1998). Women in Workforce: The Cashew Nut Labourers in the State of Kerala. Research Report, New Delhi: Centre for education and Communication.
14. Lindberg, Anna (2005) Modernization and Effeminization in India: Kerala Cashew Workers Since 1930. Copenhagen: Nordic Institute of Asian Studies Press.

15. Loewenson, Rene (1997) Health Impact of Occupational Risks in the Informal sector in Zimbabve. Geneva: International labour Organization.

16. Miller, G. Tyler (1990) Living in the Environment: An Introduction to Environmental Science. Belmont: Wadsworth.

17. Stewart, T. Charles (1979) Air Pollution, Human Health and Public Policy. New York Lexington Books.

18. World Health Organization (1995) Global strategy on occupational health for all: The way to health at work. (Recommendation of the second meeting of the WHO Collaborating Centres in Occupational Health, 11-14 October 1994, Beijing, China) available at p://www.who.int/occupational_health/publications/globst rategy/en/index.

19. Annual report of the Cashew Export Promotion Council of India2017-18

20. Annual report of the Cashew Export Promotion Council of India2018-19 